\author{
С. Л. Мальченко, \\ кандидат фіз.-мат. наук, \\ асистент, \\ Криворізький педагогічний інститут \\ ДВНЗ «Криворізький національний університет»,
}

Т. О. Різніченко, учитель КГ № 91

\title{
ВИКОРИСТАННЯ ФОТОМЕТРИЧНИХ ДАНИХ НА ЛАБОРАТОРНІЙ РОБОТІ 3 АСТРОНОМІї
}

У статті доведено необхідність проведення лабораторних робіт 3 астрономії та подано розробку лабораторної роботи з теми «Фотометричне дослідження зір у зоряних скупченнях». Мета лабораторної роботи: використовуючи фотометричні дані із системи каталогів Aladin, дослідити зоряні скупчення на наявність змінних зір та «зір фону».

Ключові слова: лабораторна робота з астрономії, фотометричні дані, зоряні скупчення, змінні зорі.

В статье показана необходимость проведения лабораторных работ по астрономии и представлена разработка лабораторной работь по теме «Фотометрическое исследование звезд в звездных скоплениях». Цель такой лабораторной работы: использование фотометрических данных системь каталогов Aladin и исследование звездных скоплений на наличие переменных звезд и «звезд фона».

Ключевые слова: лабораторная работа по астрономии, фотометрические данные, звездные скопления, переменные звезды.

This paper shows the necessity of a laboratory work on a lesson of astronomy. The development of laboratory work on the theme "The photometric study of stars in stellar clusters》 is presented. The purpose of this work: the photometric data catalog system Aladin have used for the study of stellar clusters and search of variable stars and the "background stars».

Key words: laboratory work of astronomy, photometric data, stellar clusters, variable stars.

Астрономія - галузь науки, розвиток якої триває тисячоліття і проходить через географічні, вікові, статеві, расові та культурні межі. Зростаюча роль астрономії в різноманітних галузях діяльності людини спонукає підвищувати вимоги до знань учнів середньої школи з цього предмета, відповідно, i студентів фізико-математичних факультетів. Астрономія як наука виникла в результаті практичних запитів людства $\mathrm{i}$, розвиваючись разом із ним, не втратила свого практичного значення. Реалізуючи зміст навчальних програм із фізики та астрономії, учитель має звернути увагу на висвітлення сучас- 
них напрямів розвитку техніки та новітніх технологій. Окрім того, пріоритетами державної політики в галузі освіти є особистісна орієнтація освіти, підготовка людей високої освіченості і моралі, формування у молоді наукового світогляду, творчих здібностей і здатності до самостійного опанування знаннями і їх застосовування на практиці. Відповідно, тільки практичні та лабораторні роботи допомагають розв'язати ці завдання, а також наочно побачити та зрозуміти явища природи та їх закономірність, глибше ознайомитися з методикою астрономічних вимірювань та спостережень астрономічних процесів [2]. Виконання лабораторних робіт сприяє формуванню в учнів основних понять, законів, теорій, розвитку мислення, самостійності, практичних вмінь та навичок, зокрема спостережень явищ. Учні вчаться аналізувати результати експерименту, робити узагальнення та висновки. Тільки висновки, зроблені самостійно, переходять до розряду довгострокових знань. Фізика й астрономія є фундаментальними природничо-науковими дисциплінами, основою формування в учнів сучасної наукової картини світу. Тому знання і практичні вміння учнів 3 астрономії мають бути тісно пов'язані 3 сучасним станом науки і виробництва; відповідати вимогам нового високотехнологічного суспільства, яке вступило в потужні інформаційно-комп'ютерні взаємозв'язки. Проведення лабораторних робіт, які використовують реальні дані астрофізичних спостережень, допомагає активному, цілеспрямованому розумінню астрономічних явищ та створенню стійких зв’язків і асоціацій. При цьому процес виконання лабораторної роботи багато в чому відтворює процес перебігу наукової роботи: формування мети та завдань роботи, висунення гіпотези, проведення досліду або спостереження, одержання «спостережних» даних, первинне їх оброблення, обчислення, аналіз отриманих результатів та їх оформлення, формулювання висновків.

У шкільному курсі проведення лабораторних робіт ускладнюється відсутністю астрономічного обладнання та малою кількістю годин. Першу проблему можна розв'язати використовуючи комп'ютерні пакети астрономічних програм та каталоги, а також дані мережі Інтернет. Другу проблему розв'язують факультативні заняття з астрономії. Факультативні заняття в 11 класі посідають особливе місце. Вони слугують для розширення основної програми, містять складніший 
матеріал, їх відвідують найбільш зацікавлені та підготовлені учні.

У ВНЗ курс астрономії передбачає проведення лабораторних робіт, але не в усіх педагогічних закладах $є$ спеціальне астрономічне обладнання, а наявна наукова література містить застарілі і статичні дані. Тому розроблення лабораторних робіт, які використовують реальні наукові дані астрофізичних спостережень, є достатньо актуальним. Це питання $\epsilon$ актуальним і тому, що в педагогічній літературі недостатньо висвітлено методику використання астрономічних приладів $\mathrm{i}$ моделей на уроках астрономії, фізики та інших навчальних предметів, не встановлені основні дидактичні вимоги до цих засобів навчання. Не визначено й найбільш ефективні способи моделювання астрономічних явищ у процесі підготовки майбутніх учителів фізики й астрономії в умовах масової загальноосвітньої школи.

Виходячи 3 необхідності осучаснення викладання астрономії в середній школі та ВН3, ураховуючи високий пізнавальний інтерес учнів до неї, постає питання розроблення лабораторних робіт 3 астрономії без додаткового спеціального обладнання 3 використанням астрономічних програм та мережі Інтернет.

Мета статmi - розкрити зміст розроблення лабораторної роботи 3 теми «Фотометричне дослідження зір у зоряних скупченнях», яка використовує дані каталогів системи каталогів Aladin, довести важливість проведення лабораторних робіт з астрономії.

Лабораторні роботи відрізняються від звичайних уроків. Для успішного проведення лабораторної роботи учень (студент) повинен пройти кілька етапів ії підготовки. Тому насамперед потрібно уважно ознайомитися зі змістом завдання, з ясувати завдання та мету роботи, а також на високому рівні засвоїти теоретичний матеріал, який стосується роботи. Ця робота вимагає додаткової уваги, організованості та додаткових знань і вмінь проведення науково-дослідницьких робіт. Під час складання річного плану вивчення астрономії теми практичних та лабораторних робіт повинні враховувати зацікавлення, знання та вміння як учнів, так і вчителя.

У роботі пропонується проведення лабораторної роботи 3 теми «Фотометричне дослідження зір у зоряних скупченнях». Для такої роботи застосовується система каталогів, які $є$ у вільному доступі в системі Інтернет. Працювати 3 цими да- 
ними зручно використовуючи програму Aladin. Особливість такої роботи полягає в тому, що ії проводити потрібно в комп'ютерному класі та потрібний вільний доступ до мережі Інтернет. Ця робота має наукове значення, показує тісний зв'язок вивчення астрономії з науковими даними. Ії виконують науковці для пошуку змінних зір та для вивчення розсіяних скупчень, перш ніж перейти безпосередньо до їх спостережень.

1. Постановка мети і завдань.

2. Повторення теоретичного матеріалу.

На цьому етапі потрібно пригадати: що таке скупчення, їх види та особливості; що таке змінні зорі; що таке колориметрія; які є фотометричні системи та фотометричні фільтри, їх особливості.

3. Постановка завдань, які потрібно розв'язати під час виконання лабораторної роботи.

4. Пояснення виконання роботи.

5. Виконання роботи.

6. Відповіді студентами чи учнями на контрольні питання.

7. Підсумок заняття.

\section{ЛАБОРАТОРНА РОБОТА \\ ФОТОМЕТРИЧНІ ДОСЛІДЖЕННЯ ЗІР У ЗОРЯНИХ СКУПЧЕННЯХ}

Мета роботи: Використовуючи фотометричні дані із системи каталогів Aladin, дослідити зоряні скупчення на наявність змінних зір та «зір фону».

Обладнання: Комп’ютер та пакет програми Aladin.

ТЕОРЕТИЧНІ ВІДОМОСТІ

Зоряні скупчення, як більш концентровані i яскраво виражені на небі агрегати, почали виявляти й описувати ще в XVII-XVIII століттях. Однак їх роль у колообігу зоряної еволюції залишалася нез'ясованою, поки в XX столітті не було виокремлено більш розріджені та малопомітні групи молодих зір - асоціації, а потім i комплекси. Нині номенклатура внутрішньогалактичних зоряних агрегатів така:

- подвійні та кратні (тобто потрійні тощо) зоряні системи;

- розсіяні зоряні скупчення;

- кулясті зоряні скупчення; 
- зоряні асоціації.

Зоряне скупчення - гравітаційно зв'язана група зір, що має загальне походження та рухається в гравітаційному полі галактики як єдине ціле. Зоряні скупчення мають не тільки спільне походження, але й близький вік і хімічний склад. Зазвичай вони мають щільне центральне згущування (ядро), оточене менш щільною корональною областю. Діаметри зоряних скупчень знаходяться в межах від кількох до 150 парсек, причому радіуси корональних областей в кілька (інколи в десяток) раз перевищують радіуси ядер. Історично склався поділ зоряних скупчень на розсіяні (інколи називаються відкритими, галактичними) і кульові. Відмінність між ними в основному визначається масою і віком цих утворень. Розсіяні зоряні скупчення, зауважимо, містять десятки і сотні, рідко тисячі зір, а кульові - десятки і сотні тисяч зір. Прикладами розсіяних зоряних скупчень є Плеяди, Ясла, Гіади; приклади кульових зоряних скупчень - скупчення М3 в сузір'ї Гончих Псів і М13 в сузір'ї Геркулеса.

Кінематичні характеристики та просторовий розподіл кульових зоряних скупчень Галактики відображають особливості початкового розподілу в Галактиці речовини, 3 якої на ранній стадії іiі існування виникли ці утворення. У сучасну епоху зоряні скупчення в Галактиці виникають лише поблизу галактичної площини, у районах газопилових спіральних гілок. Кульові скупчення менш цікаві астрономам, тому що це старі скупчення і там майже не утворюються цікаві зорі.

Розсіяні скупчення - це багатий матеріал для астрофізичних досліджень. Наявність серед членів таких скупчень яскравих зір дає змогу вивчати на їх прикладі фізичні властивості зір. Зоряна система містить різні об'єкти: звичайні, змінні 3opi.

Змінні зорі - зорі, у яких спостерігається зміна блиску. Взагалі блиск будь-якої зірки тією чи іншою мірою змінюється 3 часом у результаті еволюції, але дуже повільно. Для належності зорі до змінних досить, щоб іiі блиск зазнав змін хоча б одного разу. Змінність зір може бути зумовлена затемненнями в тісній подвійній системі. Такі зорі називаються затемнено змінні. Обертаючись навколо спільного центру мас, подвійні зорі періодично закривають одна одну від земного спостерігача. Такі об'єкти мають постійну криву блиску. 3 аналізу кривих блиску затемнювано-змінних зір можна: визначити період обертання Т; визначити параметри орбіт 
компонентів; оцінити маси компонентів; оцінити радіус компонентів $\mathrm{R}_{1}$ i $\mathrm{R}_{2}$.

Перед тим, як почати спостереження змінних зір різної природи змінності, астрофізики повинні «знайти» ці об'єкти. Способи пошуку - piзні, одним із таких способів є дослідження скупчень й виявлення об'єктів, які мають відмінності фотометричних даних від середнього значення для більшості зір скупчення.

Одночасно зі зміною фізичних характеристик членів зоряних скупчень відбувається їх динамічна еволюція. Зі старих скупчень у нашій Галактиці збереглися лише найбільш масивні $з$ них, тобто кульові. Серед слабких членів молодих розсіяних скупчень зазвичай спостерігаються оріонові змінні зорі та змінні зорі, що спалахують. У деяких кульових скупченнях містяться змінні зорі на зразок RR Ліри i W Діви, а в розсіяних скупченнях іноді зустрічаються цефеїди. Найбільш близькі до Сонця зоряні скупчення (наприклад, Гіади), у власних рухах членів яких спостерігаються явища перспективи (напрями власних рухів при продовженні їх на небесній сфері перетинаються в одній точці), називаються рухомими. Рухомі зоряні скупчення відіграють особливу роль у проблемі визначення зоряних відстаней, так як відстані до них можуть бути надійно визначені простим геометричним методом.

Колірною, або спектрофотометричною, називається температура такого чорного тіла, випромінювання якого в певному інтервалі довжин хвиль має розподіл інтенсивності, найближчий до того, який спостерігається для всього скупчення. В астрофізиці використовують також поняття яскравісної температури. Яскравісною називається температура такого чорного тіла, яке в заданій частоті (довжині хвилі) випромінює з одиниці поверхні таку ж кількість енергії, що й досліджуване тіло.

Основним під час вивчення фізики зір є спектральний метод. Однак у багатьох випадках важливі результати можна отримати простішим шляхом, порівнюючи між собою потоки випромінювання, які досягають спостерігача, у двох чи більше спектральних інтервалах. Цей метод іноді буває єдино можливим, коли вивченню підлягають найбільш слабкі зорі, для таких об'єктів спектральний матеріал високої якості одержати важко або взагалі неможливо. Тому, якщо за допомогою світлофільтрів визначити видимі зоряні величини $\mathrm{m}_{\lambda 1} \mathrm{i}$ $\mathrm{m}_{\lambda 2}$ у двох спектральних діапазонах з ефективними довжина- 
ми хвиль $\lambda 1$ та $\lambda 2$, то різниця цих зоряних величин: $\boldsymbol{C I}=\boldsymbol{m}_{\lambda 1}-$ $\boldsymbol{m}_{\lambda 2}$ буде цілком конкретною (числовою!) характеристикою кольору зорі. Вона називається показником кольору або колор-індексом. Метод визначення показників кольору називається колориметрією.

Світлофільтром називається оптичне середовище (ним може бути пластина, виготовлена зі спеціального скла 3 кольоровими домішками, зафарбований розчин тощо), яке пропускає випромінювання лише в певній спектральній ділянці довжин хвиль. Для кожного світлофільтра можна побудувати криву пропускання, за якою визначають прозорість фільтра залежно від його товщини і довжини хвилі випромінювання (рис. 1).

Однією 3 характеристикою світлофільтра $є$ півширина кривої пропускання $\Delta \lambda$ - ширина смуги між точками кривої пропускання, для яких коефіцієнт пропускання $(\Delta \lambda)$ дорівнює половині його максимального значення. Світлофільтри, для
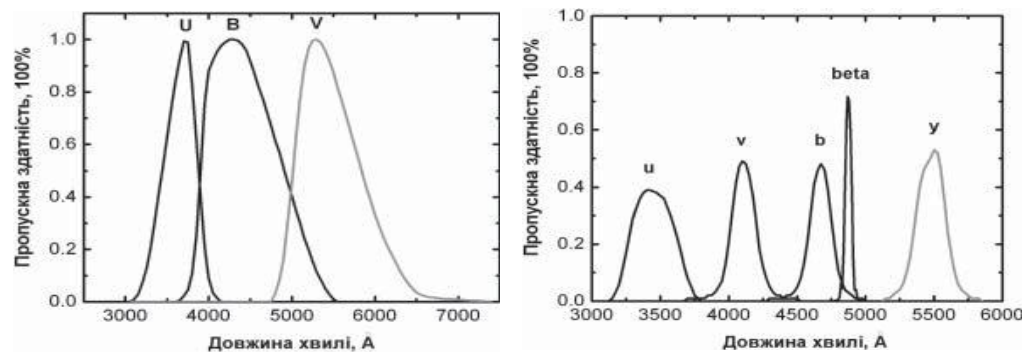

Рис. 1.

яких $\Delta \lambda>300 \AA$, називаються широкосмуговими, при $\Delta \lambda=100-300 \AA$ - середньосмуговими і при $\Delta \lambda<100 \AA$ вузькосмуговими. За вузькосмуговий фільтр іноді беруть інтерферометри Фабрі-Перо, для яких спектральна ширина пропускання випромінювання усього близько $20 \AA$.

Фотометричні характеристики зір

Для визначення яскравості зір у II ст. до н. е. грецьким астрономом Гіппархом уперше було введено термін «зоряна величина». Астрономи водночас уважали, що зорі перебувають на однаковій відстані від Землі, тому яскравість залежить від розмірів цих світил. Зараз відомо, що зорі навіть в одному сузір'ї розташовані на різних відстанях від Землі, тому видима зоряна величина визначає тільки деяку кількість енергії, яку реєструє наше око за певний проміжок часу. Гіппарх роз- 
ділив усі видимі зорі за яскравістю на 6 своєрідних сортів 6 зоряних величин. Найяскравіші зорі були названі зорями першої зоряної величини, слабкіші - другої, а найслабкіші, які ледве видно на нічному небі, - шостої. У XIX ст. англійський астроном Погсон доповнив визначення зоряної величини ще однією умовою: зорі першої зоряної величини мають бути у 100 разів яскравіші за зорі шостої величини. Позначають видиму зоряну величину літерою $\mathrm{m}$ :

$$
\frac{E_{1}}{E_{2}}=2,512^{m_{1}-m_{2}}
$$

це рівняння називають формулою Погсона. Яскравість $E$ фактично визначає освітленість, яку створюють зорі на поверхні Землі, тому величину $E$ можна вимірювати люксами одиницями освітленості, які застосовують у курсі фізики. Згідно з формулою, якщо різниця зоряних величин двох світил дорівнює одиниці, то відношення блиску буде $\approx 2,512$.

Система каталогів програми «Aladin»

Аладін становить інтерактивний атлас неба. Програмне забезпечення дозволяє користувачеві візуалізувати цифрові астрономічні зображення, накладати записи з астрономічних каталогів та баз даних і в інтерактивному режимі доступу даних і інформації з баз даних Simbad, VizieR служби та інших архівів для всіх відомих джерел в цій галузі.

Створена в 1999 році програма Аладін є інструментом, який здатний розв' язувати такі проблеми, як пошук потрібної інформації, доступ та вивчення даних астрономічних спостережень, візуалізацію даних на хвилях різної довжини. Використання системи каталогів Аладін має певні зручні інструменти: отримання існуючих або нових стандартів, можливість легко порівнювати різнорідні дані. Дана програма використовується професійними астрономами для ведення своєї науки.

\section{Хід роботи}

1. Завантажуємо програму Aladin, завантажуємо каталоги даних спостережень. У роботі потрібно вивчити такі скупчення: M92, NGC 957, NGC 457 та NGC 1444 та ін.

У головному меню обираємо рядок File і відкриваємо друге вікно натиснувши Open. 
У вікні, яке відкрилося, (Server selector) у каталозі DSS (з лівого боку), обираємо DSS from CDS(Strasbourg/FranceDSS.Aladin).

Відкрилося нове вікно у верхньому ряду Target (ICPS, name) задаємо ім'я зоряного скупчення. У ряду - Survey обираємо каталог та область довжин хвиль, у яких спостерігалося зоряне скупчення (фільтр, який використовувався під час спостережень).

2. Найбільше даних отримано у трьох діапазонах довжин хвиль: синій (B), червоний (R) та інфрачервоний (I). Тому найзручніше користуватися даними саме в цих трьох діапазонах: POSSII J DSS2-DSS2 optical B - синій, POSSII F DSS2DSS2 optical R - червоний, POSSII N DSS2-DSS2 optical I інфрачервоний.

Обираємо синій фільтр і натискаємо SUMBIT. У другому вікні відкрилося зображення зоряного скупчення яке спостерігається в синьому фільтрі. Для прикладу наведене скупчення NGC 7419. На рис. 2 показано дані, отримані для цього скупчення у синьому діапазоні.

Завантажуємо дані для червоного фільтра і натискаємо SUMBIT. Відкрилося зображення зоряного скупчення в червоному фільтрі (рис. 3). Також завантажуємо дані в інфрачервоному діапазоні (рис. 4).

3. Для зручності потрібно розділити основне вікно на чотири частини. В меню вид (під зображенням) обираємо вид «4 в 1» (чотири квадрати).

4. Потрібно об'єднати всі три зображення. У додатковому вікні (в правій частині) на панелі інструментів обираємо відповідний інструмент - rgb (значок з трьома кружками). Натиснувши цей значок, відкрилося вікно під назвою RGB image generator, де задаємо даним із каталогу відповідні кольори (у інфрачервоному діапазоні - червоний, червоному діапазоні зелений, у синьому діапазоні - синій) не забуваємо натиснути CREAT.

У результаті процедури кожне з трьох зображень «фарбується» у відповідний колір і під час накладання ми отримуємо кольорове зображення скупчення.

На отриманому малюнку зорі мають білий колір, якщо вони в усіх довжинах випромінюють однаково. Якщо ж в одному 3 трьох діапазонах мають більше випромінювання, то на малюнку зоря буде мати відповідний колір. 
Якщо зоря має щільну оболонку, то вона буде червоного кольору, якщо ж це гігант і випромінює в синьому діапазоні, то зоря буде мати синій колір, якщо зоря випромінює в чер-

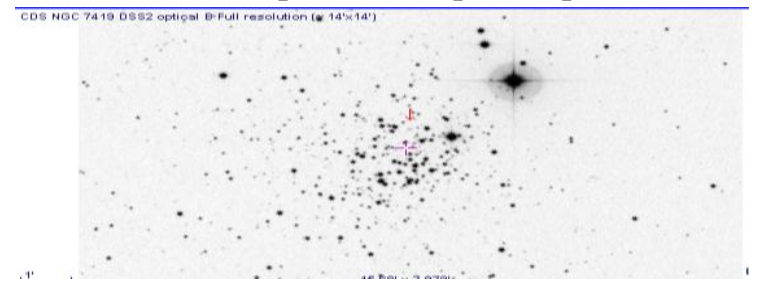

Рис.2. Вид зоряного скупчення NGC 7419 у синьому діапазоні

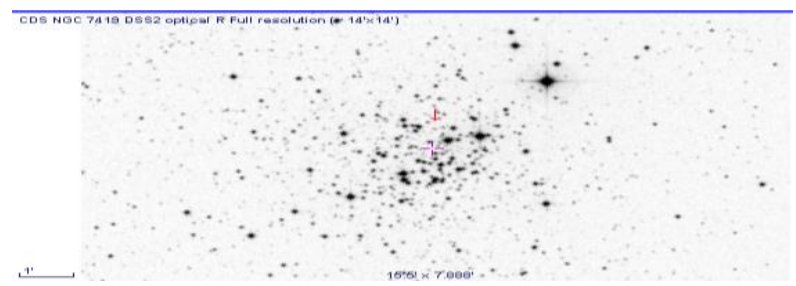

Рис.3. Вид зоряного скупчення NGC 7419 у червоному діапазоні

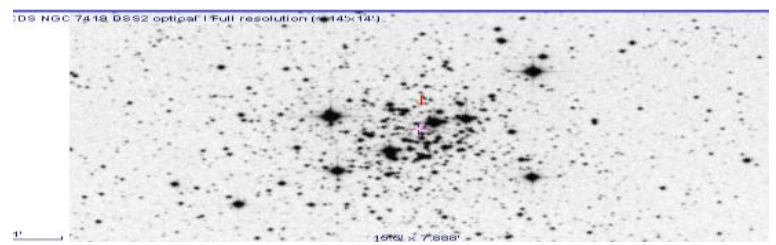

Рис.4. Зоряне скупчення NGC 7419 в інфрачервоному фільтрі.

воному діапазоні - зелений колір.

5. Потрібно визначити, який саме об'єкт має відмінний колір. Для цього завантажуємо каталог SIMBAD (спочатку у полі меню файл відкриваємо новий каталог й у правому боці обираємо відповідний каталог), задаємо ім'я скупчення. Завантажується каталог 3 назвами об'єктів. На зображеннях усі об'єкти, які будуть відомі, мають синій чи червоний кольорові фіксатори. Щоб визначити, що це за об'єкт, потрібно навести на нього курсором й у нижньому полі відкриються всі відомі дані для цієї зорі, включаючи назву та тип об'єкта. 
6. Для досягнення мети - пошук змінних об’єктів чи зір фону, які раніше були не відомі, потрібно проаналізувати кожний з кольорових об'єктів - порівняти, чи збігається отримана інформація з тією, яка є в каталогах.

7. Знайдіть та запишіть назви та інші дані для зір, колір яких відрізняється від інших. Який саме це колір? Як це можна пояснити?

8. Знайдіть у зоряному скупченні та запишіть подвійні зоpi.

9. Знайдіть змінні зорі. У якому зі скупчень спостерігаються однорідні зорі?

10. Збережіть малюнки, складіть звіт та зробіть висновки. Дайте відповіді на контрольні запитання.

1. Які основні відмінності розсіяних та кульових зоряних скупчень?

2. Пояснити, у чому полягає фотометричний метод дослідження зір?

3. Чому точніші дані одержують під час дослідження об'єктів у зоряних скупченнях, ніж поодиноких зір?

4. Які є фільтри та чим вони відрізняються?

У публікації наведено зразок лабораторної роботи з теми «Фотометричні дослідження зір», на якому використовуються дані спостережень, які є у вільному доступі у системі каталогів Aladin. Під час проведення таких лабораторних робіт можна підвищувати зацікавлення до вивчення як астрономії, так і до фізики, а також розвивати самостійність учнів, студентів і їхній науковий світогляд. Таку роботу можна проводити у школі, на факультативних заняттях 3 астрономії та у педагогічних ВНЗ на лабораторних заняттях з астрономії чи астрофізики. Досвід проведення запропонованої лабораторної роботи підтверджує його ефективність, оскільки вона усуває типову суперечність у використанні комп'ютерних засобів - підміни реального експерименту - модельним. У цьому випадку комп'ютерні технології підсилюють ефект реального експерименту i забезпечують формування знань учнів та студентів. Надалі планується продовження окресленої лінії викладання астрономії й розроблення, оприлюднення нових лабораторних робіт з астрономії.

\section{Література}

1. Андрієвський С. М. Курс загальної астрономії : [навч. посіб.] / С. М. Андрієвський, І. А. Климишин. - Одеса : Астропринт, 2007. - С. 427-431. 2. Лавут Е. Практичні роботи з астрономії : 
[методична розробка] / Е. Лавут. - Сімферополь : Мала академія наук Криму «Пошукач», 2009. - 31 с. 3. Пришляк М. П. Астрономія : [підручник для 11 класу загальноосвітніх навчальних закладів] / М. П. Пришляк. - Харків : Ранок, 2003. - 144 с.

\section{ПОНЯТТЯ «КРЕАТИВНІСТЬ»У СИСТЕМІ ПІДГОТОВКИ МАЙБУТНІХ ЕКОНОМІСТІВ В УМОВАХ ВНЗ}

У статті зроблено спробу розкрити зміст поняття «креативність» $у$ системі підготовки майбутніх економістів в умовах вищих навчальних закладів. Обтрунтовано взаємозалежність розвитку креативного компонента особистісного утворення майбутніх фахівців економічного профілю зі створення креативного навчального середовища.

Ключові слова: креативність, креативні якості, майбутні економісти, BH3.

В статье сделана попьтка раскрыть сущуность понятия «креативность» в системе подготовки будущих экономистов в условиях высших учебных заведений. Обоснована взаимосвязь развития креативного компонента личностного образования будущих профессионалов экономического профиля по образованию креативного учебной среды.

Ключевые слова: креативность, креативные качества, будущуие экономистьи, вуз.

The article attempts to uncover the essence of the concept of "creativity» in the training of future economists in higher education. Proved the relationship of the creative component of the personal education of future professionals in economics education creative learning environment.

Key words: creativity, creative quality, future economists, university.

Головною метою вищої освіти $є$ формування фахівця нової формації, здатного працювати в постійно змінюваних умовах й орієнтованого на творчу професійну діяльність. Нині функції вищої школи постійно ускладнюються, що пояснюється необхідністю швидкого реагування на попит ринку праці, гнучкості керування, адміністративногосподарської самостійності тощо.

Традиційно науковці критерієм творчих пошуків називали виготовлення потрібного нового продукту (Й. Гердер, 